\title{
IMPORTANCE OF A LEGAL FRAMEWORK IN SMART CONTRACTS
}

\section{Guillermo Martínez Cons*, Alondra Guadalupe Mora Hernández}

University Center of Economic and

Administrative Sciences,

University of Guadalajara,

Jalisco, Mexico

\section{Correspondence:}

Guillermo Martínez Cons

e-mail:

gmcons@hotmail.com

\begin{abstract}
:
Technological advances have resulted in better strategic business planning and new and innovative ways of doing business. However, not all industries adapt immediately to these transformations that, even when they have innovated with the disruptive technologies that they introduce, they have also brought with them irreversible consequences in the way in which we relate. The fourth industrial revolution that we are witnessing today shows a panorama where scientific advances are increasingly challenging traditional jobs and careers to adapt and the social sciences are no exception. In the particular case of law, new challenges are presented in those that it is essential to frame in a normative all those conducts that derive in a human connection including those that are carried out by means until recently considered unconventional, such as digital platforms and electronic encryptions that nowadays are practiced in innumerable areas, one of the most relevant ones: economic transactions.
\end{abstract}

Keywords:

Blockchain, Ethereum, Scripts, Solidity, Legislation.

\section{INTRODUCTION}

The smart contracts created by Nick Zsabo in 1994, are computer codes that replace the writing of a contract and have the ability to be fulfilled automatically once the contracting parties have agreed their terms through clauses registered in a virtual code on a Specific address of the Blockchain, these scripts allow the automation of processes in several steps. [1] The Blockchain technology works as a universal database with the hash combination for the PKI integrity (public and private key) that serves to chain the blocks and the decentralization of the records at the node scale (distributed ledger). [2] Two types of smart contracts are distinguished: the so-called smart code contracts that allude to code sequences that are stored and executed in a chain of blocks and the smart legal contracts which are not registered in it. Both have in common the existence of agreements implemented by means of codes that are executed automatically once the pre-established requirements are fulfilled through a Boolean logic in the if / then / else structure. [3] 


\section{OPERATION OF SMART CONTRACTS}

The smart contracts scripts are apt to be programmed in series and stored in the Blockchain or in protocols shared by computer networks such as Ethereum and Corda. In the case of the Bitcoin Blockchain, it supports very specific smart contracts, where the technological base lies in the combination of the Peer to Peer communication systems, with the signature or mutual trust accreditation systems that appear in the PGP system (Pretty Good Privacy). [3]

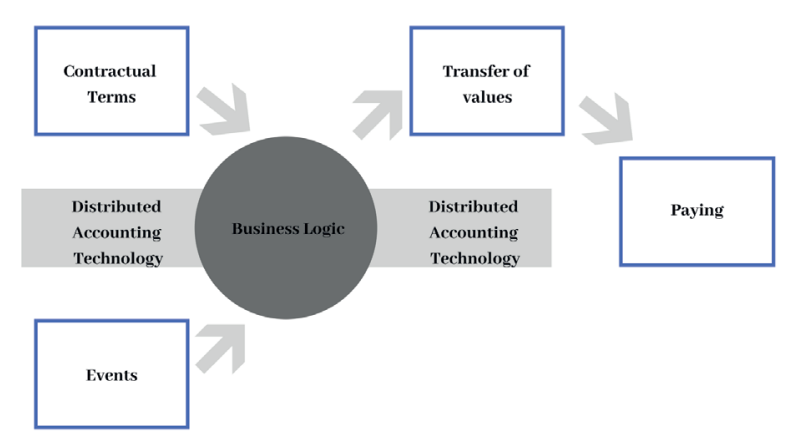

Fig. 1. Scheme of the operation of a Smart Contract

Source BBVA Research

Ethereum works as a platform with Distributed Accounting Technology (DLD) with Touring programming language that emerges as an improved version of Bitcoin cryptocurrency operations to overcome the limitations of its previous programming language, such as custody Blockchain, withdrawal limits, financial contracts, gambling market and similar ones through a very advanced programming language. [4] Ethereum employs a proprietary programming language called Solidity, a language similar to high-level Javascript that is able to interact with the Ethereum Virtual Machine (EVM), which is considered a Universal Turing Machine, a term that refers to the complete software that executes any code defined by the developer, the program written in Solidity is compiled and deployed to a node in the network in which the nodes implement the Ghost protocol (Greedy Heaviest Observed Subtree), this language allows the creation of ĐApps, ICO and smart contracts, the latter classified in algorithms programmed in decentralized applications. [5] (Fig. 1) These contracts are stored in the chain of blocks in information nodes, as it is the case with operations carried out with cryptocurrency, except that in these cases, the information instead of referring to cryptocurrency operations, includes the content in an encrypted contract. According to the World Economic Forum, Ethereum reached its highest level in January 2018 with 136,000 million euros, rising to 13,886.84 million dollars at the end of 2018. [6].

While Corda, unlike the Blockchain of Bitcoin and Ethereum is an authorized solution, that is, it is a private Blockchain, an example of this is the R3 Consortium that brings together large banks and companies with a Corda design, where these platforms are designed specifically for the requirements of the banks through a distributed accounting book prototype where, unlike the Blockchain, in the contracts registered in Corda the search for the general consensus is not one of its characteristics and although it has a structure of distributed records, access is not public and can only be accessed when two parties carry out the agreement. [5].

\section{APPLICATIONS OF SMART CONTRACTS}

The application of a smart contract arises when there is a need to manage a certain work flow defined by rules or when it is intended to ensure compliance of previously agreed conditions. [7] The effect is that, once the agreement is concluded and the triggering events are indicated, the production of these scheduled events is executed automatically, with no possibility of modification, blocking or non-execution of the benefit. [8].

Table 1. Uses of the Smart Contracts

\begin{tabular}{|c|c|}
\hline Action & Description \\
\hline $\begin{array}{l}\text { Payment } \\
\text { automation }\end{array}$ & $\begin{array}{l}\text { The required amount arrives at the } \\
\text { specified time. }\end{array}$ \\
\hline $\begin{array}{l}\text { Registration } \\
\text { and change of } \\
\text { ownership }\end{array}$ & $\begin{array}{c}\text { The documents are registered in the } \\
\text { platform to establish a property and } \\
\text { change the ownership. }\end{array}$ \\
\hline $\begin{array}{l}\text { Intellectual } \\
\text { property }\end{array}$ & $\begin{array}{l}\text { Facilitation and automation of in- } \\
\text { come. }\end{array}$ \\
\hline Insurance & $\begin{array}{l}\text { The automated incident payment pro- } \\
\text { cess between the insurer and the user. }\end{array}$ \\
\hline Betting & $\begin{array}{l}\text { A smart contract can ensure that } \\
\text { conditions are met. }\end{array}$ \\
\hline $\begin{array}{l}\text { Automatic } \\
\text { purchases }\end{array}$ & $\begin{array}{l}\text { Set up the contract for the purchase of } \\
\text { shares, cryptocurrencies or any prod- } \\
\text { uct at a fixed price for a limited time. }\end{array}$ \\
\hline Votes & $\begin{array}{l}\text { Verification of the exact results and } \\
\text { establish an immediate consequence } \\
\text { based on them }\end{array}$ \\
\hline
\end{tabular}


These functionalities intend to establish an accounting system that avoids double payment in a deal, when there is a central authority that oversees this process, the control is simple, however when performed in a medium where this figure does not exist, the development is complex, since no entity provides review and guarantee in the development. Being able to manage digital assets backed by an economic value, smart contracts can be considered as money managers, so they should be emphasized in the correct programming of them.

\section{NEED TO ESTABLISH A PROPER LEGAL FRAMEWORK FOR SMART CONTRACTS}

Contracts can be considered as agreements in which two or more involved parties agree to comply with a series of conditions. Whatever the form, they must have in mind the fundamental elements of: voluntary consent of the parties, object of the contract and a fair cause that is true and lawful. They only differ in the way of writing, its legal implication and the way of compliance. [1] That is why, in spite of being codes registered in a programmed platform, they are equally valid when complying with the minimum requirements established for these agreements.

Smart contracts protect information in an encrypted network eliminating intermediaries and providing advantages such as autonomy, security and trust, in the field of law, this type of innovation is called a suspension condition. However, among its disadvantages are the technologies that it uses: IoT and Blockchain. The first allows a link with real assets, but the devices it employs are easily hackable, the Blockchain for its part, is more secure, but it is immutable, although platforms such as Accenture are working on an editable Blockchain. [1] Similarly, we cannot talk about the total elimination of intermediaries, since in the case of poorly scheduled contracts or whose execution has not occurred as expected, it will also be necessary to go to court to resolve the arbitrariness.

In the approval of a smart contract nobody must expressly give consent, but everything works automatically and the system itself is in charge of corroborating the validity of each interaction. [9] This type of contracts does not admit clauses that need interpretation to be verified, nor do they include the concepts of "fortuitous event" and "force majeure". [3] Some tools such as Oracle allow the status of intelligent contracts to be updated with external information, while the multi-signature function allows the contract to be configured so that all parties have the duty to approve a transaction and thus a single party cannot dispose of the funds. [1].
In some cases, legal regimes are seamlessly integrated into this contracting format, but achieving a fully automated process involves resorting to online payment mechanisms that are not always adapted to the contractual type, the use of electronic money and virtual currencies make it difficult to functionality and legal security in standardized and automated forms of contracting and its use due to its scarce or null regulation and its double character of value unit and unit of account. [8] The main reason why the automatic contracting platforms do not always use digital money is due to the scarcity of the commercial offer. The money issuance sector is highly banked and credit institutions have not yet culminated with the launch and promotion of this payment instrument in the dimension that its potential provides. [8]

The novelty and at the same time difficulty in the system is that there is no intermediary-supervisor, but rather the system users themselves supervise and admit the operations, each of them through a diffuse system of mutual accreditation. A point that represents both positive and negative variables is regarding the anonymity of a subject within the Blockchain, since it provides the possibility and facility to carry out trust transactions between people from anywhere in the world without the need for an intermediary or authority. Nevertheless, in the case of a possible litigation, the knowledge of just a digital identification of the subject hinders any attempt at judicialization to resolve the misfortune. One of the discrepancies in terms of physical contracts is the exceptio non adimpleti contractus clause, that is, the exception of breach of a contract, which functions as a means of defense established in the substantive right by which it seeks to maintain contractual balance in the bilateral and onerous contracts and the central axis is the proper correlation between the reciprocal obligations of the contracting parties. Therefore, if one of the parties does not comply with its provision, the other one is not obliged to comply with its own. [10]

The business partner of Roca Junyent, a prominent firm of lawyers specializing in business law in Europe and Asia, Xavier Foz refers in this regard that "the role of lawyers is key, since on the one hand affects multiple disciplines of law; on the other hand, like any innovation, it generates situations of doubt due to the lack of specific regulation of many of its facets, which poses a challenge for jurists and opens questions regarding issues such as the liability regime of the parties involved in the process ". [11] 
Table 2. Main ĐApps in Ethereum

\begin{tabular}{|c|c|}
\hline $\begin{array}{l}\text { ĐApps in } \\
\text { Ethereum }\end{array}$ & Description \\
\hline Golem & $\begin{array}{l}\text { It is considered a supercomputer that } \\
\text { combines the power of users' comput- } \\
\text { ers. Transactions are made through the } \\
\text { cryptocurrency of the same platform, the } \\
\text { GNTs (Golem Network Tokens). }\end{array}$ \\
\hline Augur & $\begin{array}{l}\text { It combines the concepts of decentrali- } \\
\text { zation and prediction markets with the } \\
\text { commercialization of virtual actions, the } \\
\text { transactions are made in real money or } \\
\text { in cryptocurrencies. }\end{array}$ \\
\hline Aragon & $\begin{array}{l}\text { It aims to eliminate intermediaries in the } \\
\text { process of creation and maintenance of } \\
\text { organizational structures that is possible } \\
\text { through the use of the Blockchain. }\end{array}$ \\
\hline $\begin{array}{l}\text { Crypto } \\
\text { Kitties }\end{array}$ & $\begin{array}{l}\text { It is one of the first games in the world } \\
\text { that has been created based on Block- } \\
\text { chain technology, the cryptocurrency it } \\
\text { uses are its "virtual kittens" that can be } \\
\text { bought and sold. }\end{array}$ \\
\hline
\end{tabular}

The important thing is that today, there are around 12 million smart contracts only in Ethereum, the main creation platform. However, it is currently contemplated that they can be developed directly in the ĐApps, decentralized applications that allow any interaction between individuals from the web or through a mobile app without the need of a central agent to manage this service.

The State Of The ĐApps portal already collects about 1200 projects around these apps. [12] Among the advantages presented by these decentralized applications are: it provides security because the sensitive information of the users is protected against theft, manipulation or computer attacks, the information published in ĐApp format networks cannot be tracked by any central entity and failure of the service cannot happen because everything is distributed in nodes.

\section{REGULATORY INITIATIVES}

There has been little dynamism regarding the regulation of this type of activities in Latin America, among the projects contemplated by the States are the Fintech Law in Mexico that establishes the applicable regulation for the Financial Technology Institutions (ITFs) that are those of electronic payment and collective financing (crowdfunding). [8] Article 8 of this law allows the applicant company to act temporarily under a flexible regulatory framework to be able to develop new business models through the use of technological tools that do not exist in the market of financial services that it is desired to cover, this includes smart contracts. Likewise, this regulation stipulates that the Bank of Mexico, the central bank of the country, can administratively sanction anyone who carries out transactions with virtual assets or currencies without prior authorization. [13]

In Colombia, there is no rule that establishes or regulates the Blockchain, there is no restriction to do so since the principle of technological neutrality, enshrined in Law 1341 of 2009 stipulates that any type of technology can be used for any purpose legitimate you have. [4] The statute applicable to these tools in the country is the Electronic Commerce Law, adopted in 1999 as a Uniform Law model of the United Nations CNUDMI, since it is taken when considering electronic documents as data messages.[2]

The Argentinian law firm Derito launched the country's first smart contracts service for services that operate on the Blockchain, being the first platform of this type developed by lawyers in the country. Its objective aims to bring lawyers together with the technological part and search a faster and more efficient solution for contracts ending with intermediaries. Thus, the legal validity before a judicial presentation is given when issuing the contract by the office itself, even when it is intended that the conflicts are resolved in the same platform, which is expected to be ready in March 2019, and in the first stage of launching this type of software development, supply, temporary rent and deferred payment. This shall remain available for the use of people, companies and public entities. [15]

In the United States, it is the federal states and not the central government that have addressed the issue, the first state was Vermont, where after passing a law in 2016, stipulates that the documents written in the block chain are authentic as long as can obtain a verification of the date and time of registration of that information in said chain. Subsequently Arizona, in 2017 issues a law granting legal status to smart contracts. [16] While in other countries such as China the regulations on this matter are barely consolidating, the Cyberspace Administration of China (CAC) published the so-called "Regulation for the management of information services Blockchain", this document, according to local South China Morning Post, it would be the first document that contains rules that specifically regulate the Blockchain industry. Among its postulates are the mandatory registration that all Blockchain service providers must do before the CAC, in the same way users are required to 
register their real names on the platforms, thereby eliminating the privacy that these transactions provided. [17]

In Brazil, despite the form, the smart contract is legally valid when considering the principle of Article 107 of the Civil Code that ensures freedom in a contractual manner. In this way, regardless of whether a contract is written in a programming language, the legal system gives it validity since the formal requirements are subjective or objective for the effects to be produced, as far as these instruments are concerned so far. There are proposals to include and regulate the concept in the Brazilian legal system. [18]

In the European Union, in Malta, there has been an initiation of regulation that consumes many of the variants that this type of activities entails. In June 2018 Joseph Muscat, Prime Minister of this nation declared: "Malta is officially the first country in the world in having a holistic legislative framework regulating the Blockchain and DLT technology. We will be the global center for market leaders in this new sector ... "So Malta becomes the first jurisdiction to provide full legal certainty in this ecosystem with the Digital Innovation Law that allows the creation of the Digital Innovation Authority of Malta (MDIA), entity that will work autonomously and independently and will be in charge of everything concerning technological innovation and its forms of use, initially regulating only Blockchain technology and smart contracts, although it also provides government policies, education, promotion, design and use of innovative technology; while with the Law of Arrangements and Services of Innovative Technology is intended to be responsible for establishing regulations required by the MDIA to operate with cryptocurrencies. The Law of Virtual Financial Assets establishes a regulatory regime of the market in order to comply with the fundamental principles of financial regulation, protect the investor and provide integrity and financial solidity. [19]

\section{CONCLUSION}

Since the individual lives in a society, all activities have been governed in one way or another by rules, laws have served as the precepts that regulate the relationships between these subjects ensuring compliance with the rights of each one. However, advances in technology in the current era have caused many of the human actions to be subject to a controversy over its order, as new forms of interaction leave the law with many gaps in its coverage given the fact that there is no established delimitation that allows to regulate the jurisdiction.
The use of science in business is not something new, in the commercial area there are new methods every day that facilitate making operations thousands of miles away. What is surprising is that, despite the fact that a large part of the population uses these technologies in this type of transactions, such as the use of smart contracts, many legislations do not yet stipulate a legal framework that regulates commercial matters carried out in this means that allow legal certainty by assuming that those with whom it is treated will respect their commitments as in conventional agreements. Although this type of instruments have multiple advantages such as cost reduction, the elimination of intermediaries and the protection of data by being in an encrypted code, we cannot ignore that being a legitimate tool, necessarily in its creation, as throughout its validity and at the end of it must have legal supervision that allows users to have full certainty that the agreed agreement will have compliance and otherwise must trust that there will be mechanisms to restore arbitrariness. Since the language of smart contracts is unconventional to the one usually employed by lawyers, they should be directly involved in its creation to ensure that they have the conditions that provide tools in the event of a legal conflict, since it is not only about establishing conditions of use of the assets that support these operations, as has been discussed from the increase in transactions with cryptocurrencies, the entire executing system must be articulated, where the different variants involved as the transmission of personal data, the use of financial assets in the programming language and the binding of contractual law in the terms established, provide certainty to users and service providers of this type of platforms.

More and more countries are taking part in this area, some governments consider that it is nothing more than a new form of writing in the agreements, which is why they should be governed by the same regulations as the traditional ones, as in the case of Brazil, while in other countries such as Mexico, the United States and China. special laws have been specified for their ordering based on user protection, mainly with the establishment of rules of use and operation. Countries such as Argentina and Colombia do not explicitly include legislation for this type of activity, however we realize that in practice little by little they are conferring control and supervision through private entities. Nevertheless, only Malta has provided a complete and flexible legislative environment so far that has caused many Fintech companies and exchange houses to choose this country as an operation site, considering its regulatory system as one of the most accessible ones. 
What is clear without a doubt is that the ways in which we do business involve more and more technology, where it can not be assumed that everything will be fulfilled under the principle of good faith, it is essential to establish rules that are adapted to human needs that appear day by day.

\section{REFERENCES}

[1] S. Bourque and S. Fung Ling Tsui, Eds., “ ¿Qué son los contratos inteligentes?, in Criptonoticias, Agu. 2017. [Online]. Available: https://www.criptonoticias.com/ informacion/que-son-los-contratos-inteligentes/

[2] D. Peña Valenzuela. "De los contratos web a los Contratos Inteligentes. Perspectivas y Prospectiva." Universidad Externado de Colombia. https://dernegocios.uexternado.edu.co/prospectiva/de-loscontratos-web-a-los-contratos-inteligentes-perspectivas-y-prospectiva/ (accessed Mar. 20, 2019).

[3] A. Legerén-Molina, Ed., "Los contratos inteligentes en España," in Revista de Derecho Civil, Apr. 2018. [Online]. Available: https://www.nreg.es/ojs/index. $\mathrm{php} / \mathrm{RDC} /$ article/view/320/267

[4] Criptonoticias, Eds., “¿Qué es Ethereum?,” in Criptonoticias, Dec. 2017. [Online]. Available: https://www. criptonoticias.com/informacion/que-es-ethereum/

[5] J. Sandoval, Ed., "Corda, la plataforma de R3 que se asemeja muy poco a la Blockchain," in Criptonoticias, Apr. 2016. [Online]. Available: https://www.criptonoticias.com/banca-seguros/corda-la-plataforma-de-r3que-se-asemeja-muy-poco-a-la-blockchain/

[6] R. J. Maestre. "Así ha sido 2018 para las criptomonedas y esto esperamos en 2019.” World Economic Forum. https://es.weforum.org/agenda/2019/01/ asi-ha-sido-2018-para-las-criptomonedas-y-estoesperamos-en-2019/ (accesed Mar. 21, 2019).

[7] Banco Bilbao Vizcaya Argentaria. "Así son los contratos inteligentes que blindarán tus transacciones." BBVA. https://www.bbva.com/es/asi-contratosinteligentes-blindaran-tus-transacciones/ (accessed Mar. 21, 2019).

[8] M. Echevarria Saenz, Ed., "Contratos electrónicos autoejecutables (Smart contract) y pagos con tecnología Blockchain," in Revista de Estudios Europeos, Jul. 2017. [Online]. Available: http://uvadoc. uva.es/bitstream/10324/28434/1/Estudios-Europeos-2017-70-Contratos-electr\%C3\%B3nicos-autoejecutables...\%2869-97\%29.pdf

[9] Banco BilbaoVizcaya Argentaria. "QuésonlasDApps y por qué serán cada vez más importantes.” BBVA. https://www.bbva.com/es/que-son-las-dapps -y-por-que-seran-cada-vez-mas-importantes/ (accessed Mar. 23, 2019).
[10] J. A. Dos Santos Melgarejo. "La exceptio non adimpleti contractus." Columbia Paraguay. https://www. columbia.edu.py/institucional/investigacion/articulos-de-revision/212-la-exceptio-non-adimpleticontractus (accessed Mar. 24, 2019).

[11] ESADE Law School, Ed., "Blockchain y Smart Contracts, en el punto de mira legal" in ESADE Law School Journal, Feb, 2018. [Online]. Available:https://pulsosocial.com/2018/02/15/ blockchain-smart-contracts-punto-mira-legal/

[12] J. A. Plaza López, Ed., "Los 'smart contracts' no son tan perfectos como nos han vendido," in El País, Mar. 2018. [Online]. Available: https:// retina.elpais.com/retina/2018/03/05/tendencias/1520249835_156767.html

[13] B. McKenzie, Ed., "Preguntas y respuestas Ley para Regular las Instituciones de Tecnología Financiera," in El Economista, Apr. 2018. [Online].Available: https://www.eleconomista.com.mx/gestion/ Preguntas-y-respuestas-Ley-para-Regular-a-lasInstituciones-de-Tecnologia-Financiera-con-Baker-McKenzie-20180425-0050.html

[14] Revista Dinero, Eds., "Contratos inteligentes: ¿el fin de los abogados?," in Revista Dinero, Jun. 2018. [Online]. Available:https://www.dinero.com/empresas/articulo/contratos-inteligentes-con-blockchain/257066

[15] El Economista, Eds., "Somos la primer plataforma jurídica de smart contracts," in El Economista, Dec. 2018. Online]. Available: http://www.eleconomista. com.ar/2018-12-somos-la-primer-plataforma-juridica-de-smart-contracts/

[16] M. D. Martín Rodríguez. "Relación de los Smart Contracts con el derecho contractual." Miltbrait Asesores. http://milbraitasesores.com/relacion-lossmart-contracts-derecho-contractual/ (accessed Mar. 30, 2019).

[17] G. Díaz, Ed., "China emite borrador de regulaciones para servicios de información basados en Blockchain," in Criptonoticias, Oct. 2018. [Online]. Available: https://www.criptonoticias.com/regulacion/china-emite-borrador-regulaciones-serviciosinformacion-blockchain/

[18] T. Rodrigues Bernardo. "Smart Contracts - implicações para o direito privado e regulação." Jus Catarina. http://www.juscatarina.com.br/2018/01/02/ smart-contracts-implicacoes-para-o-direito-privado-e-regulacao/ (accessed Mar. 19, 2019).

[19] I. Gómez, Ed., "Malta se convierte en el primer país con una legislación integral para criptomonedas y contabilidad distribuida," in Criptonoticias, Jul. 2018. [Online]. Available: https://www.criptonoticias.com/regulacion/malta-convierte-primer-paislegislacion-integral-criptomonedas-contabilidaddistribuida/ 